\title{
Antioxidant, Antihypertensive and Antimicrobial Properties of Phenolic Compounds Obtained from Native Plants by Different Extraction Methods
}

\author{
Francisco Ramiro Boy, Rocío Casquete *(-), Ana Martínez, María de Guía Córdoba $\mathbb{C}^{\text {, }}$, Santiago Ruíz-Moyano (i) \\ and María José Benito
}

\section{check for}

updates

Citation: Boy, F.R.; Casquete, R.; Martínez, A.; Córdoba, M.d.G.;

Ruíz-Moyano, S.; Benito, M.J.

Antioxidant, Antihypertensive and

Antimicrobial Properties of Phenolic Compounds Obtained from Native Plants by Different Extraction Methods. Int. J. Environ. Res. Public Health 2021, 18, 2475. https:// doi.org/10.3390/ijerph18052475

Academic Editor: Paul B. Tchounwou

Received: 5 February 2021

Accepted: 25 February 2021

Published: 3 March 2021

Publisher's Note: MDPI stays neutral with regard to jurisdictional claims in published maps and institutional affiliations.

Copyright: (c) 2021 by the authors. Licensee MDPI, Basel, Switzerland. This article is an open access article distributed under the terms and conditions of the Creative Commons Attribution (CC BY) license (https:// creativecommons.org/licenses/by/ $4.0 /)$.
Nutrición y Bromatología, Instituto Universitario de Investigación en Recursos Agrarios (INURA), Escuela de Ingenierías Agrarias, Universidad de Extremadura, 06007 Badajoz, Spain; ramboy1@hotmail.com (F.R.B.); amartinehi@alumnos.unex.es (A.M.); mdeguia@unex.es (M.d.G.C.); srmsh@unex.es (S.R.-M.); mjbenito@unex.es (M.J.B.)

* Correspondence: rociocp@unex.es

\begin{abstract}
This study aims to evaluate the efficacy of two methods (agitation and ultra-sound) for extracting phenolic compounds from 15 native plants. Plant species collected in the Dehesa of Extremadura were used. The antioxidant, antihypertensive and antimicrobial activity of the phenolic extracts was investigated. Significantly different results were obtained when comparing the two extraction methods, with the highest concentrations of phenolic compounds found for ultrasound extraction. In addition, the extracts obtained for Cistus albidus, Cistus salviifolius, Rubus ulmifolius and Quercus ilex showed the highest concentrations of phenolic compounds. The antioxidant activity was higher in the extracts of Cistus and Q. ilex obtained by ultrasound, as was the antihypertensive activity. Antimicrobial activity was also higher in the extracts obtained by ultrasound from C. salviifolius and $Q$. ilex plants against bacteria and from Cistus ladanifer against yeasts. Therefore, it can be concluded that, with the ultrasound extraction of phenolic compounds from C. ladanifer, C. albidus and Q. ilex plants, it is possible to obtain extracts with important functional properties, so they could be studied for their use in food with the aim of obtaining healthy and safe products, favouring the sustainability of the environment of the Dehesa Extremeña.
\end{abstract}

Keywords: phenolic compounds; dehesa plants; functional properties; antimicrobial activity

\section{Introduction}

Nowadays, the importance of aromatic and medicinal plants is recognized worldwide, not only for their curative and preventive properties, but also for their uses in the pharmaceutical and food industries [1]. The Dehesa of Extremadura is characterized as an ecosystem with great biodiversity where many species of plants considered to be medicinal can be found, and are important in the pharmaceutical industry [2,3]. Among these medicinal plants are Lavandula stoechas, Malva sylvestris, Rosmarinus officinalis [4], Cistus ladanifer, C. multiflorus, C. albidus and C. salviifolius [5]. In addition to their medicinal properties, some of these plants, such as L. stoechas and M. sylvestris, are aromatic, which makes them excellent condiments for meals. However, their aroma is not the only benefit in food; their antioxidant and antimicrobial nature is also important. They can compete with chemical antioxidants that have been associated with possible health consequences (allergic reactions, disorders in pregnant women and children, possible carcinogenic action, etc.) $[6,7]$.

The functional properties of these plants, such as their antioxidant or antimicrobial properties, are due to the phenolic compounds present in their fruits, seeds, leaves, stems and flowers [8]. Phenolic compounds constitute a wide group of compounds that result from the secondary metabolism of plants found in different natural sources. The molecular 
structure of phenolic compounds has an aromatic ring containing one or more hydroxyl groups and can be a single or polymerized molecule. Depending on their structural characteristics, phenolic compounds are divided into several groups, although the main ones are phenolic acids, flavonoids, and non-flavonoids [9].

It is considered that the antioxidant properties of these compounds are due to their redox properties and chemical structure, responsible for neutralizing free radicals, chelating metals, and decomposing peroxides [10-12]. This beneficial property retards the development of diseases related to oxidative stress such as cancer, diabetes, and Alzheimer's disease [13,14], as well as anti-inflammatory activity [15]. In addition, a protective role against oxidation of unsaturated lipids in food has been observed, mainly in meat and meat products $[16,17]$.

In addition, recent studies have documented the antibacterial effects of phenol-rich extracts commonly found in plants. These studies have highlighted the use of phenolic compounds to control pathogenic bacteria, including those with a commercial antibiotic resistance profile $[18,19]$. The antibacterial effects of phenolic compounds have also been primarily associated with the presence of hydroxyl groups in their molecules. In fact, the number and position of these hydroxyl groups, i.e., the pattern of hydroxylation, in the phenolic ring, seems to be associated with the importance of the inhibitory effects exerted by the phenolic compounds on the target bacteria [20,21]. A bactericidal effect has been proven against foodborne bacteria such as Escherichia coli, Salmonella sp., Listeria monocytogenes and Staphylococcus aureus $[18,22,23]$.

Extracts obtained from plants have also been reported for their antihypertensive activity [24], although there are not many recent studies on this activity in aromatic plants. Hypertension is one of the most important factors contributing to cardiovascular diseases; therefore, it is very important to find natural compounds with this activity. Vargas-León et al. [25] attributed the antihypertensive activity of Hibiscus sabdariffa to the high number of phenolic compounds it possesses, with flavonoids and anthocyanins being the main components.

To study the biological activity of extracts, the extraction methods used are crucial since they determine the purity grade at which the phenolic compounds are extracted, and at the same time, affect all their beneficial properties previously mentioned. Thus, there are several extraction methods, including agitation and ultrasound, which are simple and cost-effective methods. In both methods, it is necessary to use a suitable solvent to extract these compounds, among which are ethanol (70-80\%), water and methanol, the last-mentioned being used in different concentrations as well as ethanol [26].

This research is an exploratory work for plant selection with the best characteristics. Therefore, this study aims to evaluate which of the two methods (agitation or ultrasound) is more effective in the extraction of phenolic compounds of different scarcely studied native plants obtained from the Extremadura Dehesa, and their influence on the functional antioxidant, antihypertensive and antimicrobial properties of the extracts obtained. The selected functional extracts could be studied for their use in food with the aim of obtaining healthy and safe products, favouring the sustainability of the Dehesa Extremeña environment.

\section{Materials and Methods}

\subsection{Plant Material}

For the development of the work, the leaves, stems, and flowers of 15 plant species (flowers from Calendula officinalis, stems from Cistus ladanifer, Cistus multiflorus, Cistus albidus, Cistus salviifolius, Lavandula stoechas, Crataegus monogyna, Malva sylvestris and Asparagus sp., and leaves from Rosmarinus officinalis, Rubus ulmifolius, Quercus ilex, Morus alba, Ulmus sp. and Urginea maritima) were used. The plants were harvested from the Extremadura region of Spain by a company located there. The samples were vacuumpacked in plastic bags and stored at $-20^{\circ} \mathrm{C}$ until they were used to extract the bioactive compounds. 


\subsection{Bacterial Strains}

Foodborne pathogenic bacteria and spoilage yeasts in food obtained from the Spanish type culture collection (CECT) were used to run the study. The pathogenic microorganisms were Staphylococcus aureus CECT 976, Bacillus cereus CECT 131, Listeria monocytogenes CECT 911, Listeria innocua CECT 910, Salmonella choleraesuis CECT 4395, Escherichia coli CECT 4267, Candida boidinii CECT 11,153, Priceomyces carsonii CECT 10,230, Kregervanrija fluxuum CECT 12,787 and Zygosacharomyces bailii CECT 11,043.

\subsection{Phenolic Compound Extraction}

The phenolic compounds were extracted from the plants by mechanical agitation (AE) and ultrasound-assisted extraction (UE).

\subsubsection{Mechanical Agitation Extraction}

Each sample $(10 \mathrm{~g})$ was extracted with $60 \mathrm{~mL}$ of $90 \%(v / v)$ ethanol-water extraction solution using an orbital shaker (Thermoshake THO 500, Gerhardt Analytical Systems, Konigswinter, Germany) set at $120 \mathrm{rpm}$ and $25^{\circ} \mathrm{C}$ for $2 \mathrm{~h}$ in darkness. After the $2 \mathrm{~h}$ of extraction, the samples were filtered. This process was repeated twice. The extracts were then kept in the dark for $24 \mathrm{~h}$ at $4{ }^{\circ} \mathrm{C}$. After that, excess ethanol was removed by heating at $37^{\circ} \mathrm{C}$ in a rotary evaporator under vacuum (Heildolph mod. Hei-VAP Precisión, Heidolph, Germany). The resultant aqueous extracts were combined to a final known volume and stored at $-20{ }^{\circ} \mathrm{C}$ until analysis.

\subsubsection{Ultrasound-Assisted Extraction}

Each sample $(10 \mathrm{~g})$ was mixed with $60 \mathrm{~mL}$ of ethanol $(90 \% v / v)$ and placed inside an ultrasonic bath ( 360 W, J.P. Selecta, s. a. Barcelona, Spain). The samples were sonicated by ultrasound at a frequency of $50 / 60 \mathrm{~Hz}$ and power of $220 \mathrm{~V}$ for $2 \mathrm{~h}$ in the absence of light at room temperature. After the $2 \mathrm{~h}$ of extraction, the samples were filtered. This process was repeated twice. The extracts were then kept in the dark for $24 \mathrm{~h}$ at $4{ }^{\circ} \mathrm{C}$. After that, excess ethanol was removed by heating at $37^{\circ} \mathrm{C}$ in a rotary evaporator under vacuum (Heildolph mod. Hei-VAP Precisión). The resultant aqueous extracts were combined to a final known volume and stored at $-20^{\circ} \mathrm{C}$ until analysis.

\subsection{Total Phenolic Content (TPC)}

The TPC of the above stored extracts was determined using Folin-Ciocalteu reagent and the method described by Wettasinghe and Shahidi [27] in a UV-1800 spectrophotometer (Shimadzu Scientific Instruments, Columbia, MD, USA). Gallic acid was used as standard. Results are expressed as mg of gallic acid equivalents (GAE)/100 g of fresh plants. All experiments were conducted in triplicate.

\subsection{Antioxidant Activity by Free Radical Scavenging Ability Using a Stable DPPH Radical and ABTS Radical Cation}

The antioxidant activity of the above stored extracts was determined by bleaching of the purple-coloured solution of 1,1-diphenyl-2-picrylhydrazyl radical (DPPH) according to the method of Teixeira et al. [28]. The total antioxidant activity was expressed as $\mathrm{mg}$ of Trolox $/ 100 \mathrm{~g}$ of fresh plants. All experiments were conducted in triplicate.

The free radical scavenging capacity of extracts was also determined using the ABTS (2,2'-azino-bis-(3-ethylbenzothiazoline-6-sulfonic acid)) radical cation decolorization assay, according to the procedure proposed by Cano et al. [29], slightly modified $(n=3)$. The initial absorbance value at $\lambda 730 \mathrm{~nm}$ was then compared to the absorbance obtained after $20 \mathrm{~min}$ of reaction. The results were expressed as $\mathrm{mg}$ of Trolox/100 $\mathrm{g}$ of fresh plants.

\subsection{Assessment of ACE Inhibitory Activity}

The extracts were diluted in $40 \%$ methanol $(v / v$ water) at a concentration of 400-100 $\mu \mathrm{g} / \mathrm{mL}$, then 1:2, 1:4 and 1:8 dilutions with Milli-Q water were done. Angiotensin- 
converting enzyme (ACE) inhibition activity was determined according to the method developed by Sentandreu and Toldrá $[30,31]$ with some modifications. ACE, previously dissolved in 50\% glycerol, was diluted in $0.15 \mathrm{M}$ Tris buffer ( $\mathrm{pH} 8.3$ ) containing $0.1 \mathrm{mM}$ $\mathrm{ZnCl}_{2}$ with $0.04 \mathrm{U} / \mathrm{mL}$ of enzyme in the final reaction solution. Into 96-well microplates (black polystyrene, Porvair, Leatherhead, UK), $40 \mu \mathrm{L}$ of distilled water or the ACE working solution was added. Then, the reaction mixture was adjusted to $80 \mu \mathrm{L}$ by adding distilled water to the blank (B), control (C) or sample (S). A sample blank (SB) was prepared by substituting distilled water for the sample to take into consideration the interference of the compounds. The reaction was begun by adding $160 \mu \mathrm{L}$ of $0.45 \mathrm{mM}$ o-Abz-Gly-p-Phe $\left(\mathrm{NO}_{2}\right)$-Pro-OH (Bachem Feinchemikalien, Bubendorf, Switzerland) dissolved in $150 \mathrm{mM}$ Tris-base buffer ( $\mathrm{pH} 8.3$ ), with $1.125 \mathrm{M} \mathrm{NaCl}$, and was incubated at $37^{\circ} \mathrm{C}$. The fluorescence was registered at $30 \mathrm{~min}$ using a multiscan microplate fluorimeter (FLUOstar optima, BMG Labtech, Offenburg, Germany). The emission and excitation wavelengths were 420 and $350 \mathrm{~nm}$, respectively, and data were processed using FLUOstar control (version 1.32 R2, BMG Labtech). The activity of each sample was tested in triplicate. Inhibitory activity is defined as the compound concentration required to inhibit the original ACE activity. The formula applied to determine the percentage of ACE inhibitory activity was: $100 \times[(C-B)-(S-S B)] /(C-B)$.

Then, the concentration of 50\% inhibition (IC50) was obtained by linear interpolation from the graphical representation of the fractional activity vs. the phenolic extract concentration. IC50 is the phenolic concentration $(\mu \mathrm{g} / \mathrm{mL})$ required to decrease ACE activity by $50 \%$ under the assayed conditions, graphically obtained where Vi inhibitor/Vi control $=0.5$.

\subsection{Antimicrobial Activity}

Target cell suspensions (Section 2.2) were prepared from cultures incubated overnight at 37 and $25{ }^{\circ} \mathrm{C}$ on brain-heart infusion agar (BHI; Oxoid, Madrid, Spain) and yeast peptone and dextrose extract agar (YPD; Oxoid, Madrid, Spain) for the bacteria and yeast, respectively. After the incubation time, colonies were transferred to a sterile Peptone Water solution (Scharlab, Barcelona, Spain) to obtain a turbidity equivalent to $0.5 \mathrm{McF}$ arland standards. Next, $1 \mathrm{~mL}$ of each suspension was pipetted into separate sterile petri dishes to which $20 \mathrm{~mL}$ of molten BHI and YPD with $1 \%$ agar $\left(45^{\circ} \mathrm{C}\right)$ for the bacteria and yeast, respectively, were added. Once set, $10 \mu \mathrm{L}$ of aqueous extracts at different concentrations $(2$, 1 and $0.5 \mathrm{mg} / \mathrm{mL}$ ) was added. Sterile distilled water, instead of active compounds, was used as the negative control. The plates were incubated overnight at 37 and $25^{\circ} \mathrm{C}$ for the bacteria and yeast, respectively, and the diameter $(\mathrm{mm})$ of the resulting inhibition zone was measured. All experiments were conducted in triplicate.

\subsection{Statistical Analysis}

Statistical analysis of the data was carried out using SPSS for Windows, version 21.0 (SPSS Inc., Chicago, IL, USA). Descriptive statistics of the data were determined, and the differences within and between groups were studied by one-way and three-way analysis of variance (ANOVA) and separated by Tukey's honest significant differences test $(p<0.05)$. In addition, principal component analysis (PCA) on the correlation matrix of the variables was performed using SPSS for Windows, 203 version 21.0 (SPSS Inc., Chicago, IL, USA).

\section{Results and Discussion}

The total phenolic compounds obtained by the two extraction methods used, agitation and ultrasound, from the different plants used in the study are presented in Table 1. 
Table 1. Total phenolic compounds of plants expressed in mg of gallic acid equivalents (GAE)/100 g fresh plant.

\begin{tabular}{cccc}
\hline \multirow{2}{*}{ Plant } & Agitation & Ultrasound & \multirow{2}{*}{$\mathbf{p}^{\mathbf{2}}$} \\
\cline { 2 - 3 } & Mean SD $^{\mathbf{1}}$ & Mean SD & \\
\cline { 2 - 3 } Calendula officinalis & $276.73 \pm 13.41^{\mathrm{cde}}$ & $95.46 \pm 2.24^{\mathrm{hi}}$ & $<\mathbf{0 . 0 1}$ \\
Rosmarinus officinalis & $160.72 \pm 14.93^{\mathrm{de}}$ & $314.01 \pm 14.65^{\mathrm{fghi}}$ & $\mathbf{0 . 0 0 1}$ \\
Cistus ladanifer & $802.89 \pm 45.52^{\mathrm{ab}}$ & $655.05 \pm 62.55^{\mathrm{cdef}}$ & $\mathbf{0 . 0 3}$ \\
Cistus multiflorus & $408.66 \pm 52.27^{\mathrm{cde}}$ & $514.26 \pm 39.86^{\mathrm{fgh}}$ & 0.08 \\
Cistus albidus & $580.25 \pm 93.34^{\mathrm{bc}}$ & $1260.47 \pm 472.40^{\mathrm{a}}$ & 0.152 \\
Cistus salviifolius & $554.8 \pm 59.73^{\mathrm{bc}}$ & $1029.99 \pm 140.38^{\mathrm{ab}}$ & $\mathbf{0 . 0 4 8}$ \\
Lavandula stoechas & $1029.25 \pm 23.15^{\mathrm{a}}$ & $554.07 \pm 13.66^{\mathrm{egg}}$ & $<\mathbf{0 . 0 1}$ \\
Crataegus monogyna & $387.96 \pm 29.43^{\mathrm{cd}}$ & $855.23 \pm 18.67^{\mathrm{bcde}}$ & $<\mathbf{0 . 0 1}$ \\
Malva sylvestris & $67.00 \pm 9.33^{\mathrm{de}}$ & $156.32 \pm 6.69^{\mathrm{hi}}$ & $\mathbf{0 . 0 0 1}$ \\
Rubus ulmifolius & $305.24 \pm 8.79^{\mathrm{cde}}$ & $953.61 \pm 76.27^{\mathrm{abc}}$ & $<\mathbf{0 . 0 0 1}$ \\
Quercus ilex & $387.54 \pm 36.58^{\mathrm{cd}}$ & $927.84 \pm 112.79 \mathrm{abcd}$ & $\mathbf{0 . 0 0 1}$ \\
Morus alba & $26.95 \pm 3.92^{\mathrm{de}}$ & $286.38 \pm 10.07 \mathrm{ghi}$ & $<\mathbf{0 . 0 0 1}$ \\
Ulmus sp. & $131.71 \pm 22.41^{\mathrm{de}}$ & $263.36 \pm 3.17^{\mathrm{ghi}}$ & $\mathbf{0 . 0 0 1}$ \\
Asparagus sp. & $92.08 \pm 4.19^{\mathrm{de}}$ & $302.57 \pm 18.61^{\mathrm{fghi}}$ & $<\mathbf{0 . 0 0 1}$ \\
Urginea maritima & $7.95 \pm 5.21^{\mathrm{e}}$ & $57.94 \pm 3.71^{\mathrm{i}}$ & $<\mathbf{0 . 0 0 1}$ \\
\hline
\end{tabular}

${ }^{1}$ SD: standard deviation. ${ }^{2} p$ values of the variable extraction methods. ${ }^{\text {a-i }}$ Values with different superscript letters are significantly different $(p<0.05)$ between plants.

In general, when the two extraction methods were compared, it was found that there were significant differences, the highest values being found for the ultrasound extraction. The concentrations of phenolic compounds obtained by ultrasound ranged from 57.94 to $1260.47 \mathrm{mg} \mathrm{GAE} / 100 \mathrm{~g}$, and those obtained by agitation ranged from 26.95 to $1029.25 \mathrm{mg}$ $\mathrm{GAE} / 100 \mathrm{~g}$. This agrees with the results reported by Bimakr et al. [32] in which ultrasound extraction allowed for the acquisition of $152.25 \mathrm{mg}$ GAE/g from Malva sylvestris, while only $128.88 \mathrm{mg} \mathrm{GAE} / \mathrm{g}$ was obtained by agitation. In a different research, the ultrasound extraction efficiency was also higher, showing a maximum value of $16.41 \mathrm{mg} \mathrm{GAE} / \mathrm{g}$ of blueberry pomace, while the conventional agitation method showed a maximum value of $5.08 \mathrm{mg} \mathrm{GAE} / \mathrm{g}$ [33]. Due to the above, it can be said that extraction by ultrasound proved to be more effective.

Furthermore, comparing the plants it can be observed that Cistus albidus, C. salviifolius, Rubus ulmifolius and $Q$. ilex were the ones with the highest phenolic compound concentrations obtained, the levels being between $927.84 \mathrm{mg}$ and $1260.47 \mathrm{mg} \mathrm{GAE} / 100 \mathrm{~g}(p<0.05)$. Cistus is an aromatic plant highly valued for its functional properties, among which the phenolic compound content is remarkable. In the study performed by Abu-Orabi et al. [34], the concentrations of phenolic compounds in the flowers of $C$. salviifolius ranged from 111 to $183.8 \mathrm{mg} \mathrm{GAE} / \mathrm{g}$, and in the leaves from 126 to $393 \mathrm{mg} \mathrm{GAE} / \mathrm{g}$. In our study, one of the plants that presented more phenolic compounds was Q. ilex, corroborating with many studies that have demonstrated a high content of these bioactive compounds, as presented by Amessis-Ouchemoukh et al. [35]. Hadidi et al. [36] also obtained between 2103.346 and $4580.316 \mathrm{mg}$ GAE$/ 100 \mathrm{~g}$ from the leaves of this tree.

The antioxidant activity analysed by the two methods, DPPH and ABTS, and the antihypertensive activity determined by the ACE inhibitory activity of the extracts obtained from the plants are presented in Table 2 . 
Table 2. Antioxidant activity (DPPH and ABTS) expressed in mg Trolox/100 g fresh plant and IC50 values ( $\mu \mathrm{g} / \mathrm{mL}) \mathrm{of}$ ACE inhibitory activity of extracts for the different extraction methods (mechanical agitation (AE) and ultrasound-assisted extraction (UE) performed).

\begin{tabular}{|c|c|c|c|c|c|c|c|c|c|}
\hline \multirow[t]{2}{*}{ Plant } & \multicolumn{2}{|c|}{ DPPH } & \multirow[t]{2}{*}{$p^{1}$} & \multicolumn{2}{|c|}{ ABTS } & \multirow[t]{2}{*}{$p$} & \multicolumn{2}{|c|}{ IC50 } & \multirow[t]{2}{*}{$p$} \\
\hline & $\mathrm{AE}$ & UE & & $\mathrm{AE}$ & UE & & AE & UE & \\
\hline Calendula officinalis & $60.51^{c}$ & $183.69^{c}$ & $<0.001$ & $67.05^{f}$ & $335.94^{\mathrm{e}}$ & $<0.001$ & $180.19 \mathrm{bcd}$ & $153.85^{\mathrm{ab}}$ & 0.418 \\
\hline Rosmarinus officinalis & $100.98^{c}$ & $95.75^{c}$ & 0.57 & $256.66^{\mathrm{e}}$ & 273.40 ef & $<0.001$ & $139.91^{\mathrm{de}}$ & $115.86^{\mathrm{ab}}$ & 0.234 \\
\hline Cistus ladanifer & $2397.47^{\mathrm{a}}$ & $2363.34^{\mathrm{a}}$ & 0.015 & $467.93^{\mathrm{d}}$ & $753.75^{b c}$ & $<0.001$ & $11.27^{\mathrm{f}}$ & $5.85^{\mathrm{d}}$ & 0.056 \\
\hline Cistus multiflorus & $793.67 \mathrm{bc}$ & $953.12^{b c}$ & 0.007 & 374.72 de & $504.78^{\mathrm{d}}$ & $<0.001$ & $187.13^{b c d}$ & $65.46^{\mathrm{cd}}$ & 0.008 \\
\hline Cistus albidus & $276.51^{\mathrm{c}}$ & $262.64^{c}$ & 0.061 & $434.68^{\mathrm{d}}$ & $825.51^{b}$ & $<0.001$ & $30.37^{f}$ & $21.69^{\mathrm{d}}$ & 0.322 \\
\hline Cistus salviifolius & $40.27^{c}$ & $100.80^{c}$ & $<0.001$ & $804.74^{\mathrm{b}}$ & $832.72^{b}$ & 0.305 & $62.13^{\text {ef }}$ & $16.53^{\mathrm{cd}}$ & 0.107 \\
\hline Lavandula stoechas & $18.93^{c}$ & $91.23^{c}$ & $<0.001$ & $45.74^{\mathrm{f}}$ & $256.32^{f}$ & $<0.001$ & $172.47^{b c d}$ & $189.79^{a}$ & 0.362 \\
\hline Crataegus monogyna & $106.25^{c}$ & $216.46^{c}$ & 0.001 & $532.99 \mathrm{~cd}$ & $718.05^{b c}$ & 0.012 & $174.61 \mathrm{bcd}$ & $151.77^{\mathrm{ab}}$ & 0.267 \\
\hline Malva sylvestris & $37.65^{c}$ & $147.53^{c}$ & 0.001 & $77.40^{f}$ & $262.93^{f}$ & $<0.001$ & $202.73^{b c}$ & $112.92^{\mathrm{ab}}$ & 0.039 \\
\hline Rubus ulmifolius & $93.28^{c}$ & $131.50^{\mathrm{c}}$ & $<0.001$ & $644.23^{c}$ & $842.33^{b}$ & 0.001 & $315.58^{a}$ & $65.40^{\mathrm{cd}}$ & 0.036 \\
\hline Quercus ilex & $1531.95^{b}$ & $1611.59^{b}$ & 0.599 & $2531.41^{\mathrm{a}}$ & $2306.17^{a}$ & 0.117 & $198.58^{b c}$ & $80.38^{b c}$ & 0.001 \\
\hline Morus alba & $29.45^{c}$ & $255.42^{c}$ & $<0.001$ & $60.92^{f}$ & 303.40 ef & $<0.001$ & $232.66^{b}$ & $137.89^{a b}$ & 0.042 \\
\hline Ulmus sp. & $70.76^{c}$ & $366.43^{c}$ & $<0.001$ & $261.76^{\mathrm{e}}$ & $397.37^{\mathrm{e}}$ & $<0.001$ & 142.77 de & $72.63^{b c}$ & 0.055 \\
\hline Asparagus sp. & $40.32^{\mathrm{c}}$ & $244.87^{c}$ & 0.013 & $99.46^{\mathrm{f}}$ & $260.48^{f}$ & 0.002 & $110.86^{\text {de }}$ & $99.37 \mathrm{bc}$ & 0.412 \\
\hline Urginea maritima & $17.05^{c}$ & $132.08^{c}$ & 0.05 & $41.96^{f}$ & $154.62^{f}$ & 0.002 & $198.37^{b c}$ & $152.02^{\mathrm{ab}}$ & 0.032 \\
\hline
\end{tabular}

Values are given as mean $(n=3) .{ }^{1} p$ values of the variable extraction methods. ${ }^{\text {a-f }}$ Values with different superscript letters are significantly different $(p<0.05)$ between plants.

In general, it can be observed that the ABTS values were higher than those provided by the DPPH method (Table 2), which may be related to the way in which the ABTS and DPPH radicals work. However, comparing the compound extraction methods, it was found that the values obtained by ultrasound were higher than those found for agitation $(p<0.05)$ : between 91.23 and $2363.34 \mathrm{mg}$ Trolox/100 $\mathrm{g}$ for DPPH and 154.62 and $2306.17 \mathrm{mg}$ Trolox/100 $\mathrm{g}$ for ABTS. In addition, when analysing the activity according to the plants, Cistus and $Q$. ilex were the ones with the highest values, meaning that those plants showed the highest antioxidant activity. Furthermore, it can be observed that the extracts with the highest antioxidant activity were not those with the highest total phenolic compound concentrations, which may be due to the different compound compositions $[37,38]$. The genus Cistus is one of the plants with greater beneficial properties, among which its antioxidant activity, related to its phenolic compound content extracted mainly with ethanol is highlighted [39]. Among the species highlighted for their antioxidant character is $Q$. ilex, which is reported in this study and supported by other studies such as that by Arina and Harisun [40], who obtained $90 \%$ radical inhibition.

Hypotensive activity, expressed as IC50, measures the amount of any substance needed to inhibit $50 \%$ of ACE. Table 2 shows that the phenolic compounds extracted from Cistus multiflorus, Malva sylvestris, R. ulmifolius, Q. ilex, Morus alba and Urginea marina using ultrasound had a lower IC50 $(p<0.05)$ than those extracted by agitation. This means that, with a smaller amount of these compounds, the ACE activity is reduced to half and ultrasound is more effective as an extraction method. However, within the plants, it can be observed that species of the genus Cistus, among them C. albidus, C. ladanifer and C. salviifolius, were the ones with a lower IC50, with values between $5.85 \mu \mathrm{g} / \mathrm{mL}$ (C. ladanifer) and $21.69 \mu \mathrm{g} / \mathrm{mL}$ (C. albidus). Additionally, R. ulmifolius, with an IC50 of $65.40 \mu \mathrm{g} / \mathrm{mL}$, was also found within these plants with lower IC values. This activity is directly related to the phenolic compound content, so that the higher the amount of these bioactive compounds, the higher the ACE inhibitory activity. This fact has been confirmed in this study and in others such as the one presented by Chaudhary et al. [41] on several medicinal plants.

Table 3 shows statistical analysis of the variables studied (plants, extraction method and concentration) and the antimicrobial effect on the six pathogenic bacteria analysed, as well as their interactions $(p<0.05)$. 
Table 3. Diameter of inhibition zones in mm of different concentrations of plant extracts tested that showed activity against bacteria.

\begin{tabular}{|c|c|c|c|c|c|c|}
\hline & L. Monocytogenes & L. Innocua & S. Aureus & B. Cereus & E. Coli & S. Choleraesuis \\
\hline Plant & Mean SD & Mean SD & Mean SD & Mean SD & Mean SD & Mean SD \\
\hline Cistus multiflorus & - & - & - & - & - & $5.26 \pm 4.68^{c}$ \\
\hline Cistus albidus & $1.62 \pm 2.40^{\mathrm{d}}$ & $2.89 \pm 4.28^{\mathrm{d}}$ & $3.19 \pm 4.72^{\mathrm{d}}$ & $2.62 \pm 3.87^{c}$ & $2.35 \pm 3.47^{g}$ & $5.28 \pm 2.80^{c}$ \\
\hline Cistus ladanifer & $1.85 \pm 2.76^{c}$ & $3.23 \pm 4.78^{c}$ & $3.22 \pm 3.57^{d}$ & $3.00 \pm 4.46^{\mathrm{b}}$ & $2.86 \pm 4.24 \mathrm{e}$ & $7.82 \pm 2.97^{\mathrm{a}}$ \\
\hline Cistus salviifolius & $0.83 \pm 1.93 \mathrm{~g}$ & $5.29 \pm 4.10^{\mathrm{a}}$ & $3.28 \pm 3.56^{\mathrm{d}}$ & - & $4.25 \pm 3.28^{b}$ & $4.22 \pm 3.79^{d}$ \\
\hline Lavandula stoechas & $1.38 \pm 3.21^{\mathrm{e}}$ & - & $1.49 \pm 3.48^{\mathrm{f}}$ & - & - & $0.87 \pm 2.03^{i}$ \\
\hline Quercus ilex & $3.88 \pm 4.69^{\mathrm{a}}$ & $3.56 \pm 4.04^{b}$ & $5.45 \pm 2.97^{\mathrm{a}}$ & $3.79 \pm 3.34^{\mathrm{a}}$ & $5.07 \pm 3.86^{\mathrm{a}}$ & $6.27 \pm 3.55^{b}$ \\
\hline Rosmarinus officinalis & $1.15 \pm 2.69^{\mathrm{f}}$ & - & $1.88 \pm 2.91^{\mathrm{e}}$ & $0.99 \pm 2.32 \mathrm{e}^{\mathrm{f}}$ & $0.00 \pm 0.00^{\mathrm{k}}$ & - \\
\hline Rubus ulmifolius & $2.18 \pm 3.23^{b}$ & $2.76 \pm 3.56^{\mathrm{d}}$ & $3.98 \pm 3.08^{c}$ & $1.89 \pm 2.81^{\mathrm{d}}$ & $3.93 \pm 2.93^{c}$ & $3.57 \pm 2.06^{\mathrm{f}}$ \\
\hline Crataegus monogyna & - & - & $1.85 \pm 2.76^{\mathrm{e}}$ & - & $3.75 \pm 3.98^{d}$ & - \\
\hline Asparagus sp. & - & - & - & - & $2.00 \pm 2.95^{h}$ & - \\
\hline Malva sylvestris & - & - & $4.3 \pm 6.60^{b}$ & $3.88 \pm 5.73^{\mathrm{a}}$ & $2.56 \pm 3.79^{\mathrm{f}}$ & $3.37 \pm 4.98^{\mathrm{f}}$ \\
\hline Morus alba & - & - & - & - & - & $3.85 \pm 5.69^{\mathrm{e}}$ \\
\hline Urginea maritima & - & - & $1.18 \pm 2.76^{\mathrm{g}}$ & $1.04 \pm 2.44^{\mathrm{e}}$ & $1.37 \pm 3.19^{\mathrm{i}}$ & $1.52 \pm 3.54^{g}$ \\
\hline Ulmus sp. & - & - & $1.16 \pm 2.71^{g}$ & $0.86 \pm 2.00^{f}$ & $1.18 \pm 2.76^{j}$ & $1.19 \pm 2.78 \mathrm{~g}$ \\
\hline Extraction method & & & & & & \\
\hline Agitation & $0.63 \pm 1.99$ & $0.85 \pm 2.53$ & $2.30 \pm 3.41$ & $1.38 \pm 3.00$ & $2.19 \pm 3.33$ & $2.66 \pm 3.78$ \\
\hline Ultrasound & $1.21 \pm 2.71$ & $1.68 \pm 3.35$ & $2.13 \pm 3.77$ & $1.20 \pm 2.93$ & $1.99 \pm 3.27$ & $3.51 \pm 4.18$ \\
\hline \multicolumn{7}{|l|}{ Concentration $(\mathrm{mg} / \mathrm{mL})$} \\
\hline 2 & $2.10 \pm 3.33^{\mathrm{a}}$ & $2.44 \pm 4.12^{\mathrm{a}}$ & $4.95 \pm 4.44^{\mathrm{a}}$ & $3.39 \pm 4.18^{\mathrm{a}}$ & $4.34 \pm 3.86^{\mathrm{a}}$ & $5.76 \pm 4.80^{\mathrm{a}}$ \\
\hline 1 & $0.51 \pm 1.85^{b}$ & $0.95 \pm 2.38^{b}$ & $1.36 \pm 2.41^{b}$ & $0.40 \pm 1.48^{b}$ & $1.75 \pm 2.82^{b}$ & $2.36 \pm 3.07^{b}$ \\
\hline 0.5 & $0.15 \pm 0.80^{c}$ & $0.41 \pm 1.49^{c}$ & $0.34 \pm 1.24^{c}$ & $0.08 \pm 0.42^{c}$ & $0.19 \pm 0.99^{c}$ & $1.14 \pm 2.09^{c}$ \\
\hline Pplants & $<0.001$ & $<0.001$ & $<0.001$ & $<0.001$ & $<0.001$ & $<0.001$ \\
\hline Pextraction & $<0.001$ & $<0.001$ & $<0.001$ & $<0.001$ & $<0.001$ & $<0.001$ \\
\hline Pconcentration & $<0.001$ & $<0.001$ & $<0.001$ & $<0.001$ & $<0.001$ & $<0.001$ \\
\hline Pplant $\times$ extraction & $<0.001$ & $<0.001$ & $<0.001$ & $<0.001$ & $<0.001$ & $<0.001$ \\
\hline
\end{tabular}

-: no inhibition; ${ }^{\mathrm{a}-\mathrm{k}}$ : values with different superscript letters indicate statistical differences $(p<0.05)$.

Concerning the study of the plants' effect, it can be observed that $C$. salviifolius and $Q$. ilex presented a greater inhibition capacity on the six pathogenic bacteria studied $(p<0.05)$. The rest of the plants belonging to the genus Cistus (C. multiflorus, C. albidus and C. ladanifer) presented a greater inhibition capacity against Salmonella choleraesuis. R. ulmifolius presented a greater inhibition capacity against Listeria monocytogenes, S. aureus and E. coli.

Regarding the extraction method, greater inhibition capacity was obtained through ultrasound against three of the six bacteria studied: L. monocytogenes, L. innocua and S. choleraesuis.

The concentration of extract also affected this activity, since the higher its concentration, the higher its inhibition capacity, with $2 \mathrm{mg} / \mathrm{mL}$ being the concentration with the greatest antimicrobial capacity against the six bacteria studied. Therefore, the genus Cistus is highlighted for its antimicrobial capacity. This agrees with the results obtained by Mahmoudi et al. [42] who, after studying the antimicrobial activity of two species of the genus Cistus, observed higher activity against $E$. coli. It is commonly known that Gram-positive bacteria are more susceptible to natural extracts and Gram-negative ones are less sensitive to natural extracts. Nevertheless, there are exceptions in which Gram-negative bacteria are more susceptible than Gram-positive ones towards some natural extracts [43], highlighting the susceptibility of E. coli.

In addition, Quercus extract contains metabolites belonging to various chemical groups; the phenolic compounds (benzoics, cinnamics, coumarins, stilbenes, flavonoids, lignans and tannins) are the most representative. Other groups include carbohydrates, amino acids, fatty acids, carboxylic acids, and other secondary metabolites, terpenoids and alkaloids [44]. Some of these compounds have been previously reported as antimicrobial compounds in Q. ilex and another Quercus spp. [45]. The antimicrobial activity of this genus has been proven against various microorganisms, including E. coli and S. aureus. This activity depends on the species and the extract obtained, as well as the method of acquisition [46]. 
Based on the results, it is possible to state that the antibacterial activity is influenced by the method of extracting phenolic compounds, the concentration and the plant extract used.

Table 4 shows the statistical analysis of the variables studied (plants, extraction method and concentration) and the antimicrobial effect on the four spoilage yeasts analysed, as well as their interactions $(p<0.05)$.

Table 4. Diameter of inhibition zones in mm of different concentrations of plant extracts tested that showed activity against yeasts.

\begin{tabular}{|c|c|c|c|c|}
\hline \multirow{2}{*}{ Plant } & C. Boidinii & K. Fluxuum & P. Carsonii & Z. Bailii \\
\hline & Mean SD & Mean SD & Mean SD & Mean SD \\
\hline Cistus albidus & $2.83 \pm 4.2^{d}$ & $5.17 \pm 4.11^{b}$ & $4.87 \pm 3.76^{c}$ & $5.31 \pm 3.04^{c}$ \\
\hline Cistus ladanifer & $7.55 \pm 2.7^{\mathrm{a}}$ & $7.83 \pm 3.21^{\mathrm{a}}$ & $8.11 \pm 3.08^{\mathrm{a}}$ & $7.69 \pm 2.93^{a}$ \\
\hline Cistus salviifolius & $1.62 \pm 3.79 \mathrm{e}$ & $4.53 \pm 4.04^{\mathrm{bc}}$ & - & $1.31 \pm 3.06^{\mathrm{d}}$ \\
\hline Lavandula stoechas & - & $1.54 \pm 2.98^{\mathrm{d}}$ & $2.33 \pm 3.50^{d}$ & $1.33 \pm 3.09^{d}$ \\
\hline Quercus ilex & $5.46 \pm 6.09^{b}$ & $7.53 \pm 4.89^{\mathrm{a}}$ & $3.37 \pm 4.65^{b}$ & $6.52 \pm 5.03^{b}$ \\
\hline Rosmarinus officinalis & - & $1.025 \pm 2.39^{d}$ & $1.2 \pm 2.80^{\mathrm{e}}$ & - \\
\hline Rubus ulmifolius & $3.15 \pm 4.89^{c}$ & $3.51 \pm 3.71^{\mathrm{c}}$ & $1.01 \pm 2.37^{\mathrm{f}}$ & $1.16 \pm 2.71^{\mathrm{e}}$ \\
\hline \multicolumn{5}{|l|}{ Extraction method } \\
\hline Agitation & $1.87 \pm 3.57$ & $3.62 \pm 3.41$ & $2.76 \pm 3.73$ & $3.24 \pm 4.14$ \\
\hline Ultrasound & $4.02 \pm 5.04$ & $5.27 \pm 5.01$ & $3.78 \pm 4.43$ & $3.42 \pm 4.26$ \\
\hline \multicolumn{5}{|l|}{ Concentration (mg/mL) } \\
\hline 2 & $5.97 \pm 5.53^{\mathrm{a}}$ & $7.05 \pm 5.26^{\mathrm{a}}$ & $5.88 \pm 4.87^{\mathrm{a}}$ & $6.12 \pm 4.89^{a}$ \\
\hline 1 & $2.14 \pm 3.53^{b}$ & $4.79 \pm 2.83^{b}$ & $3.20 \pm 3.31^{b}$ & $2.87 \pm 3.46^{b}$ \\
\hline 0.5 & $0.73 \pm 1.83^{c}$ & $1.51 \pm 2.49^{\mathrm{c}}$ & $0.73 \pm 1.82^{c}$ & $0.99 \pm 1.96^{\mathrm{c}}$ \\
\hline Pplants & $<0.001$ & $<0.001$ & $<0.001$ & $<0.001$ \\
\hline Pextraction & $<0.001$ & $<0.001$ & $<0.001$ & $<0.001$ \\
\hline Pconcentration & $<0.001$ & $<0.001$ & $<0.001$ & $<0.001$ \\
\hline Pplant $\times$ extraction & $<0.001$ & $<0.001$ & $<0.001$ & $<0.001$ \\
\hline
\end{tabular}

-: no inhibition; ${ }^{\text {a-f: }}$ values with different superscript letters indicate statistical differences $(p<0.05)$.

Cistus ladanifer showed a greater inhibition capacity against the four studied spoilage yeasts and C. albidus showed greater capacity against $K$. fluxuum, P. carsonii and Z. bailii $(p<0.05$; Table 3$)$. A greater inhibition capacity of $Q$. ilex can also be observed against C. boidinii, K. fluxuum and Z. bailii.

In addition, greater inhibition capacity against the studied yeasts was obtained with ultrasound extraction, and the highest concentration of extracts, $2 \mathrm{mg} / \mathrm{mL}$, showed a greater antimicrobial capacity.

Ceylan et al. [47] performed studies with several aromatic plants and observed their activity against yeasts of the genus Candida.

When comparing the results presented in Tables 3 and 4 , it can be observed that plants with activity against bacteria do not show activity against yeasts or do so to a lesser extent. That was the case for C. salviifolius, R. ulmifolius and Malva sylvestris. The first two presented lower activity against yeasts compared to bacteria (Table 3); M. sylvestris did not present any activity against the studied yeasts, so it was not included in Table 4.

Q. ilex is also described as having antimicrobial and antifungal properties. Merghache et al. [48] demonstrated the inhibition capacity of the wood ashes of $Q$. ilex against yeasts even at low concentrations (5\%).

Therefore, as previously stated for antibacterial activity, based on the results, antifungal activity is influenced by the method of extracting phenolic compounds, the concentration and the plant extract used.

Finally, the PCA developed with the different parameters studied, to determine the relevance of each parameter in the plant extracts obtained with the two extraction methods used, is shown in Figure 1. 


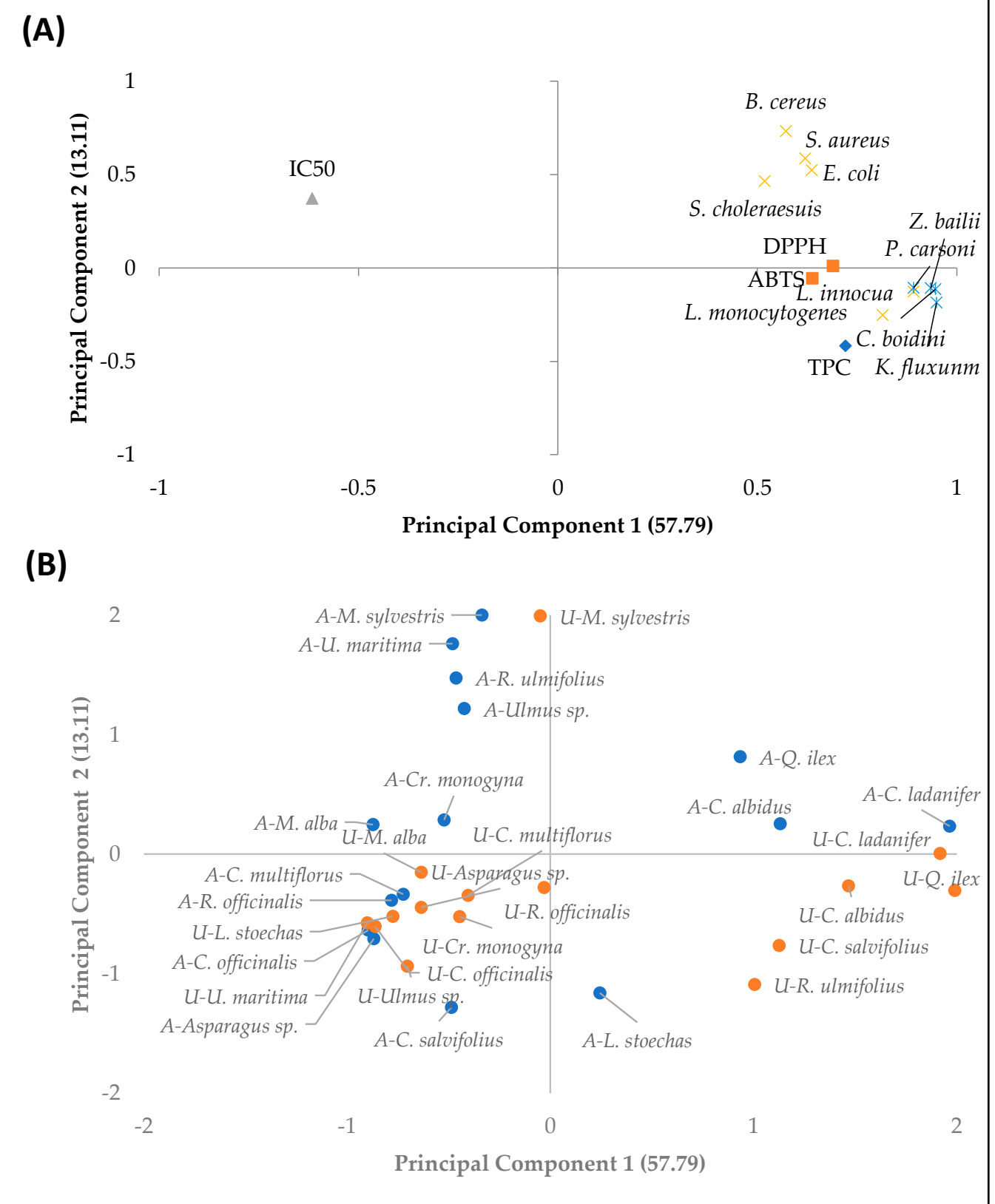

Figure 1. Principal component analysis of the parameters analysed in the extracts from different plants extracted by agitation (A) and ultrasound (U). Loading plot (A). TPC: total phenolic compounds; DPPH and ABTS: antioxidant activity of extracts; IC50: extract concentration $(\mu \mathrm{g} / \mathrm{mL})$ required to reduce $50 \%$ of ACE; B. cereus, S. aureus, E. coli, S. choleraesuis, L. innocua and L. monocytogenes: antimicrobial activity against each of the bacteria; Z. bailii, P. carsonii, C. boidinii and K. fluxuum: antimicrobial activity against each of the yeasts. Score plot (B). Plant extracts extracted by agitation (blue); plant extracts extracted by ultrasound (orange).

Figure 1 shows that the Q. ilex extracts extracted by ultrasound (U) and those of C. ladanifer extracted by both methods (A and $U$ ) are located on the negative and positive axes, respectively, of the main component 1 defined by antimicrobial activity against yeast, explaining $57.79 \%$ of the total variance. The $M$. sylvestris extracts were associated with the main component 2 (13.11\% of the total variance), with the positive part defined by antimicrobial activity against $B$. cereus bacteria.

Among the observed results, it can be highlighted that the extracts obtained by ultrasound from the plants belonging to the genera Cistus, especially C. ladanifer and C. albidus, and Quercus (Q. ilex), were the ones that presented the highest number of 
phenolic compounds, and highest antioxidant and antimicrobial activity. It was also possible to observe that the extracts of the genus Cistus, highlighting C. ladanifer extracted by ultrasound, were the ones that presented the best results for antihypertensive activity, since the concentration $(\mu \mathrm{g} / \mathrm{mL})$ of extract necessary to inhibit $50 \%$ of ACE is lower, which explains why the IC50 is in the opposite plane for these plant extracts.

\section{Conclusions}

In general, when the two extraction methods used to obtain phenolic compounds were compared, it was found that there were significant differences, with the highest values found for ultrasound extraction. In addition, the extracts obtained from Cistus albidus, C. salviifolius, R. ulmifolius and Q. ilex were the ones with the highest concentrations of phenolic compounds. The antioxidant activity was higher in the Cistus and Q. ilex extracts obtained by ultrasound, as was the antihypertensive activity. The antimicrobial activity was also higher in the extracts obtained by ultrasound from C. salviifolius and Q. ilex plants against bacteria and $C$. ladanifer against yeast.

Therefore, it can be concluded that, by ultrasound extraction of the phenolic compounds from the plants C. ladanifer, C. albidus and Q. ilex, it is possible to obtain extracts with significant functional properties, so that they could be studied for their use in food with the aim of obtaining healthy and safe products, favouring the sustainability of the Dehesa Extremeña environment.

Author Contributions: Conceptualization, R.C., M.J.B. and M.d.G.C.; methodology, R.C., S.R.-M. and A.M.; formal analysis, F.R.B. and A.M.; investigation, F.R.B.; resources, F.R.B. and R.C.; data management, R.C. and A.M.; writing-original draft preparation, R.C. and M.J.B.; writing-review and editing, R.C.; visualization, A.M.; supervision, M.J.B. and M.d.G.C.; funding acquisition, M.d.G.C. All authors have read and agreed to the published version of the manuscript.

Funding: Junta de Extremadura with the projects IB16158 and GR18165.

Institutional Review Board Statement: Not applicable.

Informed Consent Statement: Not applicable.

Data Availability Statement: Not applicable.

Acknowledgments: The authors are grateful to M. Cabrero and J. Hernández Barreto for technical assistance.

Conflicts of Interest: The authors declare no conflict of interest.

\section{References}

1. Quílez, M.; Ferreres, F.; López-Miranda, S.; Salazar, E.; Jordán, M.J. Seed oil from Mediterranean aromatic and medicinal plants of the Lamiaceae family as a source of bioactive components with nutritional. Antioxidants 2020, 9, 510. [CrossRef]

2. Blanco Salas, J.; Vázquez, F.M.; Alonso, D.; Gutierrez Esteban, M.; Márquez-García, F.; Chaparro, J.; Barrena, M.; Ramos, S.; Hércules, S. Recursos fitogenéticos de las dehesas extremeñas: Plantas medicinales. In Proceedings of the V Congreso Forestal Español, Ávila, Spain, 21-25 September 2009.

3. Costa, D.C.; Costa, H.S.; Albuquerque, T.G.; Ramos, F.; Castilho, M.C.; Sanches-Silva, A. Advances in phenolic compounds analysis of aromatic plants and their potential applications. Trends Food Sci. Technol. 2015, 45, 336-354. [CrossRef]

4. Pacheco, D.P.; Villalobos, J.R. Contribución al conocimiento de nombres vernáculos de plantas medicinales en la comarca de Zafra-Río Bodión. Rev. Estud. Extremeños 2007, 63, 343-352.

5. Ruíz, T.T.; Escobar, G.P.; Pérez, C.J.L. La Serena y Sierras Limítrofes: Flora y Vegetación; Consejería de Agricultura y Medio Ambiente, Junta de Extremadura: Mérida, Spain, 2007.

6. Kamala Kumari, P.V.; Akhila, S.; Srinivasa Rao, Y.; Rama Devi, B. Alternative to artificial preservatives. Sys. Rev. Pharm. 2019, 10, S13-S16.

7. Suhaj, M. Spice antioxidants isolation and their antiradical activity: A review. J. Food Compost. Ana 2006, 19, 531-537. [CrossRef]

8. Brewer, M.S. Natural antioxidants: Sources, compounds, mechanisms of action, and potential applications. Comp. Rev. Food Scif. 2011, 10, 221-247. [CrossRef]

9. Li, A.N.; Li, S.; Zhang, Y.J.; Xu, X.R.; Chen, Y.M.; Li, H.B. Resources and biological activities of natural polyphenols. Nutrients 2014, 6, 6020-6047. [CrossRef] 
10. Chun, S.S.; Vattem, D.A.; Lin, Y.T.; Shetty, K. Phenolic antioxidants from clonal oregano (Origanum vulgare) with antimicrobial activity against Helicobacter Pylori. Process. Biochem. 2005, 40, 809-816. [CrossRef]

11. Moon, J.K.; Shibamoto, T. Antioxidant assays for plant and food components. J. Agric. Food Chem. 2009, 57, 1655-1666. [CrossRef] [PubMed]

12. Zulueta, A.; Esteve, M.J.; Frígola, A. ORAC and TEAC assays comparison to measure the antioxidant capacity of food products. Food Chem. 2009, 114, 310-316. [CrossRef]

13. Kumar, H.; Bhardwaj, K.; Nepovimova, E.; Kuča, K.; Dhanjal, D.S.; Bhardwaj, S.; Bhatia, S.K.; Verma, R.; Kumar, D. Antioxidant functionalized nanoparticles: A combat against oxidative stress. J. Nanomater. 2020, 10, 1334. [CrossRef]

14. Pate, K.M.; Rogers, M.; Reed, J.W.; van der Munnik, N.; Vance, S.Z.; Moss, M.A. Anthoxanthin polyphenols attenuate A $\beta$ oligomer-induced neuronal responses associated with Alzheimer's disease. CNS Neurosci. Ther. 2017, 23, 135-144. [CrossRef]

15. Crozier, A.; Jaganath, I.B.; Clifford, M.N. Dietary phenolics: Chemistry, bioavailability and effects on health. Nat. Prod. Rep. 2009, 26, 1001-1043. [CrossRef]

16. Burri, S.C.; Ekholm, A.; Bleive, U.; Jensen, M.; Hellstr, J.; Mńkinen, S.; Korpineng, R.; Mattilah, P.H.; Radenkovsi, V.; Seglinai, D.; et al. Lipid oxidation inhibition capacity of plant extracts and powders in a processed meat model system. Meat. Sci. 2020, 162, 108033. [CrossRef]

17. Lourenço, S.C.; Moldão-Martins, M.; Alves, V.D. Antioxidants of natural plant origins: From sources to food industry applications. Molecules 2019, 24, 4132. [CrossRef] [PubMed]

18. Cáceres, M.; Hidalgo, W.; Stashenko, E.; Torres, R.; Ortiz, C. Essential oils of aromatic plants with antibacterial, anti-biofilm and anti-quorum sensing activities against pathogenic bacteria. Antibiotics 2020, 9, 147. [CrossRef]

19. Gomes, F.; Dias, M.I.; Lima, Â.; Barros, L.; Rodrigues, M.E.; Ferreira, I.C.; Henriques, M. Satureja montana L. and Origanum majorana L. decoctions: Antimicrobial activity, mode of action and phenolic characterization. Antibiotics 2020, 9, 294. [CrossRef] [PubMed]

20. Oh, E.; Jeon, B. Synergistic anti-Campylobacter jejuni activity of fluoroquinolone and macrolide antibiotics with phenolic compounds. Front. Microbiol. 2015, 6, 1129. [CrossRef] [PubMed]

21. Sanhueza, L.; Melo, R.; Montero, R.; Maisey, K.; Mendoza, L.; Wilkens, M. Synergistic interactions between phenolic compounds identified in grape pomace extract with antibiotics of different classes against Staphylococcus aureus and Escherichia coli. PLoS ONE 2017, 12, e0172273. [CrossRef]

22. Vieitez, I.; Maceiras, L.; Jachmanián, I.; Alborés, S. Antioxidant and antibacterial activity of different extracts from herbs obtained by maceration or supercritical technology. J. Supercrit. Fluid 2018, 133, 58-64. [CrossRef]

23. Weerakkody, N.S.; Caffin, N.; Turner, M.S.; Dykes, G.A. In vitro antimicrobial activity of less-utilized spice and herb extracts against selected food-borne bacteria. Food Control 2010, 21, 1408-1414. [CrossRef]

24. Mihailovic-Stanojevic, N.; Belščak-Cvitanović, A.; Grujić-Milanović, J.; Ivanov, M.; Jovović, D.; Bugarski, D.; Miloradović, Z. Antioxidant and antihypertensive activity of extract from Thymus serpyllum L. in experimental hypertension. Plant Foods Hum. Nutr. 2013, 68, 235-240. [CrossRef] [PubMed]

25. Vargas-León, E.A.; Díaz-Batalla, L.; González-Cruz, L.; Bernardino-Nicanor, A.; Castro-Rosas, J.; Reynoso-Camacho, R.; GómezAldapa, C.A. Effects of acid hydrolysis on the free radical scavenging capacity and inhibitory activity of the angiotensin converting enzyme of phenolic compounds of two varieties of jamaica (Hibiscus sabdariffa). IND Crops Prod. 2018, 116, 201-208. [CrossRef]

26. Caldas, T.W.; Mazza, K.E.; Teles, A.S.; Mattos, G.N.; Brígida, A.I.S.; Conte-Junior, C.A.; Borguini, G.R.; Godoy, L.R.; Cabral, L.M.C.; Tonon, R.V. Phenolic compounds recovery from grape skin using conventional and non-conventional extraction methods. IND Crops Prod. 2018, 111, 86-91. [CrossRef]

27. Wettasinghe, M.; Shahidi, F. Evening primrosemeal: A source of natural antioxidants and scavenger of hydrogen peroxide and oxygen-derived free radicals. J. Agric. Food Chem. 1999, 47, 1801-1812. [CrossRef]

28. Teixeira, D.M.; Canelas, V.C.; Martins do Canto, A.; Teixeira, J.M.G.; Dias, C.B. HPLC-DAD quantification of phenolic compounds contributing to the antioxidant activity of Maclura pomifera, Ficus carica and Ficus elastica extracts. Anal. Lett. 2009, 42, 2986-3003. [CrossRef]

29. Cano, A.; Acosta, M.; Armao, M.B. A method to measure antioxidant activity in organic media: Application to lipophilic vitamins. Redox Rep. 2000, 5, 365-370. [CrossRef]

30. Sentandreu, M.A.; Toldrá, F. A rapid, simple and sensitive fluorescence method for the assay of angiotensin-I converting enzyme. Food Chem. 2006, 97, 546-554. [CrossRef]

31. Sentandreu, M.A.; Toldrá, F. A fluorescence-based protocol for quantifying angiotensin-converting enzyme activity. Nat. Protoc. 2006, 1, 2423-2427. [CrossRef]

32. Bimakr, M.; Ganjloo, A.; Zarringhalami, S.; Ansarian, E. Ultrasound-assisted extraction of bioactive compounds from Malva sylvestris leaves and its comparison with agitated bed extraction technique. Food Sci. Biotechnol. 2017, 26, 1481-1490. [CrossRef]

33. He, B.; Zhang, L.L.; Yue, X.Y.; Liang, J.; Jiang, J.; Gao, X.L.; Yue, P.X. Optimization of ultrasound-assisted extraction of phenolic compounds and anthocyanins from blueberry (Vaccinium ashei) wine pomace. Food Chem. 2016, 204, 70-76. [CrossRef] [PubMed]

34. Abu-Orabi, S.T.; Al-Qudah, M.A.; Saleh, N.R.; Bataineh, T.T.; Obeidat, S.M.; Al-Sheraideh, M.S.; Al-Jaber, H.I.; Tashtoush, H.I.; Lahham, J.N. Antioxidant activity of crude extracts and essential oils from flower buds and leaves of Cistus creticus and Cistus salviifolius. Arab. J. Chem. 2020, 13, 6256-6266. [CrossRef] 
35. Amessis-Ouchemoukh, N.; Ouchemoukh, S.; Meziant, N.; Idiri, Y.; Hernanz, D.; Stinco, C.M.; Rodríguez-Pulido, F.J.; Heredia, F.J.; Madani, K.; Luis, J. Bioactive metabolites involved in the antioxidant, anticancer and anticalpain activities of Ficus carica L., Ceratonia siliqua L. and Quercus ilex L. extracts. IND Crops Prod. 2017, 95, 6-17. [CrossRef]

36. Hadidi, L.; Babou, L.; Zaidi, F.; Valentão, P.; Andrade, P.B.; Grosso, C. Quercus ilex L.: How season, plant organ and extraction procedure can influence chemistry and bioactivities. Chem. Biodivers 2017, 14, e1600187. [CrossRef] [PubMed]

37. Márquez, C.J.; Otero, C.M.; Rojano, B.A.; Osorio, J.A. Actividad Antioxidante y Concentración de Compuestos Fenólicos del Tomate de Árbol (Cyphomandra betacea S.) en Poscosecha. Temas Agrarios 2014, 19, 173-184. [CrossRef]

38. Puertas-Mejía, M.A.; Rivera-Echeverry, F.; Villegas-Guzmán, P.; Rojano, C.B.A.; Palaez-Jaramillo, C. Comparación entre el Estado de Maduración del Fruto de Café (Coffee arabica L.), el Contenido de Antocianinas y su Capacidad Antioxidante. Rev. Cuba. Plantas Med. 2012, 17, 360-367.

39. Stępień, A.; Aebisher, D.; Bartusik-Aebisher, D. Biological properties of Cistus species. Eur. J. Clin. Exp. Med. 2018, 16, 127-132. [CrossRef]

40. Arina, M.I.; Harisun, Y. Effect of extraction temperatures on tannin content and antioxidant activity of Quercus infectoria (Manjakani). Biocatal. Agric. Biotechnol. 2019, 19, 101104. [CrossRef]

41. Chaudhary, N.; Sabikhi, L.; Hussain, S.A.; Sathish Kumar, M.H. A comparative study of the antioxidant and ACE inhibitory activities of selected herbal extracts. J. Herb. Med. 2020, 22, 100343. [CrossRef]

42. Mahmoudi, H.; Aouadhi, C.; Kaddour, R.; Gruber, M.; Zargouni, H.; Zaouali, W.; Ben Hamida, N.; Ben Nasri, M.; Ouerghi, Z.; Hosni, K. Comparison of antioxidant and antimicrobial activities of two cultivated Cistus species from Tunisia. J. Biosci. 2016, 32, 226-237. [CrossRef]

43. Kalemba, D.; Kunicka, A. Antibacterial and antifungal properties of essential oils. Curr. Med. Chem. 2003, 10, 813-829. [CrossRef] [PubMed]

44. López-Hidalgo, C.; Trigueros, M.; Menéndez, M.; Jorrin-Novo, J.V. Phytochemical composition and variability in Quercus ilex acorn morphotypes as determined by NIRS and MS-based approaches. Food Chem. 2021, 338, 127803. [CrossRef]

45. Karioti, A.; Sokovic, M.; Ciric, A.; Koukoulitsa, C.; Bilia, A.R.; Skaltsa, H. Antimicrobial properties of Quercus ilex L. proanthocyanidin dimers and simple phenolics: Evaluation of their synergistic activity with conventional antimicrobials and prediction of their pharmacokinetic profile. J. Agric. Food Chem. 2011, 59, 6412-6422. [CrossRef] [PubMed]

46. Burlacu, E.; Nisca, A.; Tanase, C. A comprehensive review of phytochemistry and biological activities of Quercus species. Forests 2020, 11, 904. [CrossRef]

47. Ceylan, S.; Cetin, S.; Camadan, Y.; Saral, O.; Ozsen, O.; Tutus, A. Antibacterial and antioxidant activities of traditional medicinal plants from the Erzurum region of Turkey. Ir. J. Med. Sci. 2019, 188, 1303-1309. [CrossRef] [PubMed]

48. Merghache, D.; Boucherit-Otmani, Z.; El Haci, I.A.; Chikhi, I.; Boucherit, K. Inhibitory effect of Quercus ilex wood ash on the growth of pathogenic microorganisms. Phytothérapie 2018, 16, S269-S272. [CrossRef] 